\title{
OPTIMATION OF GLYCEROL CARBONATE FROM REACTING GLYCEROL AND UREA USING LIMESTONE AS CATALYST SOURCE
}

\author{
Megawati ${ }^{1}$, Alimuddin $^{2}$, Laode Abdul $\operatorname{Kadir}^{3 *}$ \\ ${ }^{1}$ Chemistry Program Study, Faculty Of Science and Technology, Universitas Sembilanbelas November \\ Kolaka, 93517, Kolaka, Indonesia. \\ ${ }^{2}$ Chemistry Education Program Study, Faculty Of Teacher Training And Education, Universitas \\ Sembilanbelas November Kolaka, 93517, Kolaka, Indonesia \\ ${ }^{3}$ Chemistry Department, Faculty Of Mathematic and Natural Sciences, Universitas Haluoleo, 93132, \\ Kendari, Indonesia \\ *Corresponding Author:kadir20512048@gmail.com
}

\begin{abstract}
Abstrak. Penelitian tentang sintesis dan optimasi gliserol karbonat dari gliserol dan urea menggunakan batu kapur alam sebagai sumber katalis telah dilakukan. penelitian itu bertujuan untuk menghasilkan gliserol karbonat dengan menggunakan katalis $\mathrm{CaCO}_{3}$ dan $\mathrm{CaO}$ dari batu kapur alam yang tersebar luas di Sulawesi Tenggara. Katalis ini dibuat melalui proses kalsinasi batu kapur pada suhu $750^{\circ} \mathrm{C}$ selama 3 jam kemudian dikarakterisasi menggunakan X-Ray Flourescence (XRF). Katalis yang telah diperoleh ditambahkan dalam gliserol dan urea (substrat) untuk menguji sifat katalisnya melalui reaksi karbamoilasi dengan rasio mol substrat 1:1 dengan konsentrasi katalis $5 \%$ massa terhadap gliserol. Optimasi reaksi dilakukan dengan mengubah beberapa parameter reaksi yaitu temperatur, waktu reaksi dan rasio katalis terhadap reaktan. Identifikasi produk dilakukan menggunakan Fourier Tansform Infrared Spectroscopy (FTIR) dan didukung oleh data Gas Chromatography (GC). Optimasi suhu,waktu dan konsentrasi katalis pada reaksi katalisis diperoleh pada temperatur $140 \mathrm{oC}$ selama 4 jam dan menggunakan rasio mol katalis terhadap substrat 5\%
\end{abstract}

Kata kunci: Gliserol karbonat, Katalis, Batu Kapur alam

\begin{abstract}
Synthesis of glycerol carbonate from glycerol and urea using natural limestone as a catalyst source has been conducted. The research aims to produce glycerol carbonate using $\mathrm{CaCO}_{3}$ and $\mathrm{CaO}$ As catalysts from limestone which is widespread in Southeast Sulawesi.This catalyst was made from calsined limestone at a $750^{\circ} \mathrm{C}$ for 3 hours and then characterized using X-Ray Fluorescence (XRF). The catalyst obtained was added to glycerol and urea (substrate ) to test the catalyst properties with a 1: 1 mole substrate ratio with a catalyst concentration of 5\% mass to glycerol. Reaction optimization was cunducted by changing reaction parameters namely temperature, reaction time and the ratio of catalyst to reactant. Characterization Product using Fourier Tansform Infrared Spectroscopy (FTIR) and Gas Chromatography (GC) . Optimization of temperature, time and catalyst concentration in the catalysis reaction was obtained at $140^{\circ} \mathrm{C}$ for 4 hours and using a catalyst mole ratio to $5 \%$ substrate
\end{abstract}

Keywords: Glycerol Carbonate, Catalyst, Limestone

\section{INTRODUCTION}

Glycerol carbonate (4hydroxymethyl-1,3-dioxolan-2-one) is the one of a glycerol derivative that has several uses such as elastomer, surfactant, adhesive, ink, paint, lubricant, electrolyte, and as important intermediate from polycarbonate, polyester, polyurethane, and polyamide. Glycerol have a dual function in which there is a cyclic carbonate group and a nucleophilic hydroxy group, this dual function compound that allows these 
compounds to be used as a protective polar solvent, and safe for the environment. this compound can be applied to various organic and inorganic compounds as solvent, for example in the fields of cosmetics, paints, accumulators, and others (Damayanti et al., 2012).

The synthesis of glycerol carbonate (4-hydroxymethyl-1,3-dioxolan-2-one) from glycerol and urea is a new method to increase the use value of glycerol as a byproduct of the biodiesel industry. This topic has taken a lot of attention from chemists, because it has many advantages, for example reducing $\mathrm{CO}_{2}$ emissions because it is used in the synthesis reaction of glycerol carbonate (Zhou et al., 2008) and can replace the route of synthesis of glycerol carbonate from toxic substances such as phosgene and CO (Jerome et al., 2008).

The synthesis route and type of catalyst used to produce glycerol carbonate have been reported based on literature studies such as the reaction of glycerol and dimethyl carbonate (Ochoa-Gomez et al., 2009). However, this reaction route produces ethylene glycol (a by-product) that is difficult to separate from the product (Turney et el., 2013). The catalysts that have been used in this reaction are $\mathrm{ZnSO} 4$ (Zhang et al., 2003), MgSO4 (Okutsu, 2007). Both are quite effective homogeneous catalysts. Other catalysts that have been studied are $\mathrm{Al} / \mathrm{MgOx}, \mathrm{Al} /$ LiOx metal oxide mixture (Zhou et al., 2008), zirconium phosphate (Zhou et al., 2008), Co3O4 / ZnO (Rubio-Marcos et al., 2010), La2O3 (Wang et al., 2011), Au nanoparticles (Hammond et al., 2011), and zinc monoglycerate (Turney et al., 2013). Some catalysts have produced a high conversion reaching $70 \%$ with selectivity $<100 \%$ at temperatures of $135 \mathrm{oC}$. In addition $83 \%$ conversion was obtained at 140 oC using zinc monoglycerate as a catalyst (Turney et al., 2013). Another route being developed at this time is the reaction of glycerol and urea through the carbamoylation-carbonation reaction used a Lewis acid catalyst. In this method, glycerol and urea are reacted with the same equivalent mole ratio under conditions of temperature $130-150 \mathrm{oC}$ in vacuum conditions followed by the separation of ammonia gas to maintain the equilibrium reaction. Some catalysts used in this reaction are Ni-based metal catalysts (Damayanti et al, 2012), ZnSO4 (Jimmy et al., 2015). Although several catalysts have been developed for the production of glycerol carbonate with quite good efficiency, however the reaction mechanism and the synthesis methods are still a topic that need to be developed to produce catalysts with high performance in normal conditions.

Limestone is a one of natural rock type that is widely available in Indonesia especially in Southeast Sulawesi. it is a type of sedimentary rock containing carbonate compounds. in general, the limestone are containing calcium carbonate $\left(\mathrm{CaCO}_{3}\right)$ crystal form calcite. This rock has white yellowish white, gray to black color surfaces. this rock is formed from the remains of shellfish as well as from the process of chemical precipitation with Density ranges 2.6 to $2.8 \mathrm{~g} / \mathrm{cm} 3$ in a pure state with the crystalline form of calcite $\left(\mathrm{CaCO}_{3}\right)$ (Lukman et al., 2012).

The other calcium carbonate crystal form in limestone is aragonite $\left(\mathrm{CaCO}_{3}\right)$ which is a unstable mineral because at certain times it can change to calcite $\left(\mathrm{CaCO}_{3}\right)$ (Sucipto et al., 2007).The latest industrial products from limestone are ground calcium carbonate flour (GCC) and Precipitate Calcium carbonate (PCC) as a substitute for kaolin in paper industry (Aziz, 2010). Calcite mineral (CaCO3) is 
the most stable phase and is widely used in the paint, paper, magnetic recording, textile, detergent, plastic, and cosmetics industries (Lailiyah et al., 2012). The calcium carbonate mineral can be converted to calcium oxide $(\mathrm{CaO})$ through calcination to obtain pure calcium $(\mathrm{Ca})$ which is used as a catalyst. therefore, limestone can be used as a catalyst source.

In this paper, the researcher developed a method of synthesizing glycerol carbonate by designing a catalyst derived from limestone and applying it to produce glycerol carbonate. This catalyst is expected to be a catalyst that has good catalytic properties. Therefore, this research is expected to be able to provide information about the continued use of local limestone of Kolaka which has been used as building material and has potential in the field of research and technology that can be developed

\section{MATERIAL AND METHOD Instrumentation}

Oven, Furnace, Fourier Tansform Infrared Spectroscopy (FTIR) Alpha Bruker, Gas Chromatography Techcomp D-7900E, X-Ray Flourescence (XRF) ED Epsilon 3.

\section{Materials}

Limenstone, glycerol $\left(\mathrm{C}_{3} \mathrm{H}_{5}(\mathrm{OH})_{3}\right)$, urea $\left(\mathrm{CO}\left(\mathrm{NH}_{3}\right)_{2}\right)$, aquadest, methanol $\left(\mathrm{CH}_{3} \mathrm{OH}\right)$ p.a

\section{METHODS}

\section{Preparation of catalyst}

Limestone is obtained from home industries in Pomala subdistrict, Kolaka, Southeast Sulawesi. The limestone is cleaned using aquadest and dried on the oven for 1 hour at $100 \mathrm{oC}$. then, the limestone is crushed using mortar and pastel until to be lime powder $(\mathrm{CaCO} 3)$ and filtered using a 200 mesh sieve. 30 gram $\mathrm{CaCO} 3$ is calcined at 750 oC for 3 hours and then characterized using X- Ray Flourescence (XRF)

\section{Synthesis Glyserol Carbonates (Catalyst Test) \\ Glycerol $50 \mathrm{mmol}(4.6 \mathrm{~g})$ is reacted} with $50 \mathrm{mmol}$ urea $(3.0 \mathrm{~g})$, catalyst $(\mathrm{CaCO} 3$ and $\mathrm{CaO}$ ) as much as $5 \mathrm{~mol} \%$ against glycerol. This reaction is stirred at a constant rate of $640 \mathrm{rpm}$ while being heated at the temperature as tested. Then 1 $\mathrm{mL}$ methanol is added. Catalyst separated using the filtration method.

\section{Product Identification}

Glycerol carbonate analysis using FTIR to see vibration of $\mathrm{C}=\mathrm{O}$ Esters (COester 1735-1820 cm-1) and Gas Chromatography (GC) at retention time (t) 17.5 minutes. Fifth, optimization of the catalyst reaction. is carried out as in the third stage with temperature variations namely $110,120,130,140,150,160$, $170^{\circ} \mathrm{C}$. Time variations are $1,2,3,4$, and 5 hours, and variations of catalysts concentration ; 1:20, 1:40, 1: 100, 1: 1000 to the glycerol substrate $(4.6 \mathrm{~g}, 50 \mathrm{mmol})$ and urea ( $3 \mathrm{~g}, 50 \mathrm{mmol}$ ).

\section{RESULTS AND DISCUSSION 1. Preparation of catalyst}

The stages of limestone preparation starts from heating at $100^{\circ} \mathrm{C}$ to remove the water content in the rock. then proceed with calcination at $750^{\circ} \mathrm{C}$ for 3 hours to remove organic compounds that composed in limestone and to decompose $\mathrm{CaCO}_{3}$ into $\mathrm{CaO}$ which can be used as a catalyst source. XRF analysis (X Ray Fluorescence) was carried out to determine the chemical composition of the limestone shown in table 1 . 
Table 1. Composition of limestone from XRF analysis (X-Ray Flourescence )

\begin{tabular}{|c|c|c|c|c|c|c|c|c|c|c|c|c|c|c|c|}
\hline S & Weight & $\mathrm{CaO}$ & $\mathrm{CaCO}_{3}$ & $\mathbf{A l}_{2} \mathbf{O}_{3}$ & $\mathrm{Cr}_{2} \mathrm{O}_{3}$ & $\mathrm{Fe}_{2} \mathrm{O}_{3}$ & $\mathbf{K}_{2} \mathbf{O}$ & MgO & MnO & $\mathrm{Na}_{2} \mathrm{O}$ & $\mathbf{P}_{2} \mathbf{O}_{5}$ & $\mathrm{SiO}_{2}$ & $\mathrm{SO}_{3}$ & $\mathrm{TiO}_{2}$ & ZnO \\
\hline & & $\%$ & $\%$ & $\%$ & $\%$ & $\%$ & $\%$ & $\%$ & $\%$ & $\%$ & $\%$ & $\%$ & $\%$ & $\%$ & $\%$ \\
\hline $\begin{array}{c}\text { Calcined } \\
\text { limestone } \\
\left(750^{\circ} \mathrm{C}\right)\end{array}$ & 10,00 & 52,22 & 28,16 & 7,85 & 0,021 & $<0,01$ & $<0,01$ & 5,822 & 0,1 & 0,66 & $<0,01$ & 5,32 & $<0,01$ & $<0,01$ & $<0,01$ \\
\hline limestone & 10,00 & 47,53 & 32,8 & 8,69 & $<0,01$ & $<0,01$ & $<0,01$ & 7,945 & 0,1 & 0,73 & $<0,01$ & 3,09 & $<0,01$ & $<0,01$ & $<0,01$ \\
\hline
\end{tabular}

The results of analysis show that the composition of limestone has $\mathrm{CaO}$ and $\mathrm{CaCO}_{3}$ content at $47.53 \%$ and $32.8 \%$, respectively. While natural limestone calcined at a temperature of $750^{\circ} \mathrm{C}$ has $\mathrm{CaO}$ and $\mathrm{CaCO}_{3}$ at $52.22 \%$ and $28.16 \%$, respectively.

\section{Catalytic Test and Product Characterization}

The catalyst test in glycerol carbonate formation reaction is carried out by reacting glycerol and urea and calcined limestone $(\mathrm{CaO})$ as catalyst at $750^{\circ} \mathrm{C}$ and limestone without calcination $\left(\mathrm{CaCO}_{3}\right)$ with substrate mole ratio at 1:1 with a catalyst concentration of $5 \%$ mass against glycerol. Furthermore, gas nitrogen $\left(\mathrm{N}_{2}\right)$ is flowed to separate the ammonia formed as a byproduct. Urea is a source of carbonyl group and the source of ammonia gas formation in the reaction of glycerol carbonate formation. Synthesis reactions of Glycerol carbonate showed in figure 1. this Synthesis reaction namely carbamoylation/ carbonation. this method was carried out in schlenk flask without solvents and at ambient pressure at (1 atm).<smiles>CCOC(C)C(CO)C1COC(=O)O1</smiles>

Figure 1. Reaction of gìyceroi and urea to producing gìceroì carbonate

The formation of glycerol carbonate species will be characterized by changes in vibration of the carbonyl group (CO amine) to the carbonyl group (CO ester) cyclic. From the results of the catalysis test validated by FT-IR, it was seen that the carbonyl group (CO ester) was formed in the reaction catalyzed by the calcined limestone at $750^{\circ} \mathrm{C}$ as in Figure 2.
Identification of glycerol carbonate species was characterized by changes in vibration of the carbonyl group of $\mathrm{CO}$ amine to the $\mathrm{CO}$ cyclic ester. The results of the catalysis test validated by FT-IR, it was confirmed that the carbonyl group (CO ester) was formed in the reaction catalyzed by the calcined limestone at $750^{\circ} \mathrm{C}$ as in Figure 2. 


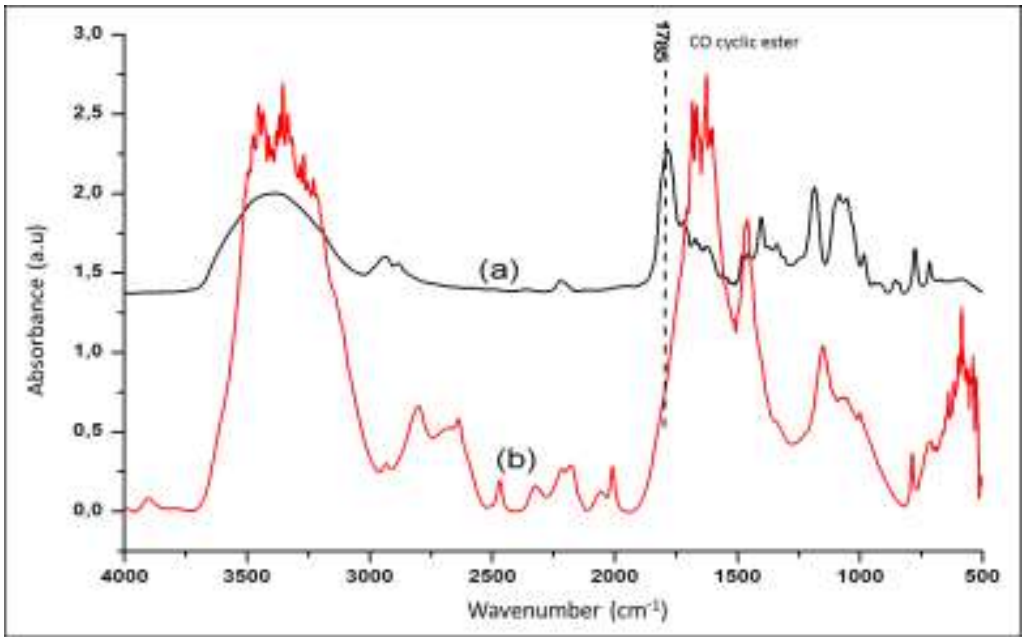

Figure 2. FTIR Spectra, (a) Product Reaction catalyzed by calcined limestone at $750^{\circ} \mathrm{C}$ and (b) product reaction catalyzed by uncalcined limestone

Based on the results of identification using FTIR (Figure 2), the vibration of the carbonyl group $(\mathrm{C}=\mathrm{O})$ ester at wave number $1785 \mathrm{~cm}^{-1}$ was indicated as a typical vibration of glycerol carbonate. This guess is reinforced by the results of stacking between the product reaction as shown in Figure 3. The condition showing a change in vibration of the urea carbonyl $(\mathrm{CO})$ amine group at wave number $1643 \mathrm{~cm}-1$ becomes a vibration of the carbonyl group (CO ester) at wave number $1786 \mathrm{~cm}^{-1}$ was indicated that glycerol carbonate has been formed. and the starting material used in the

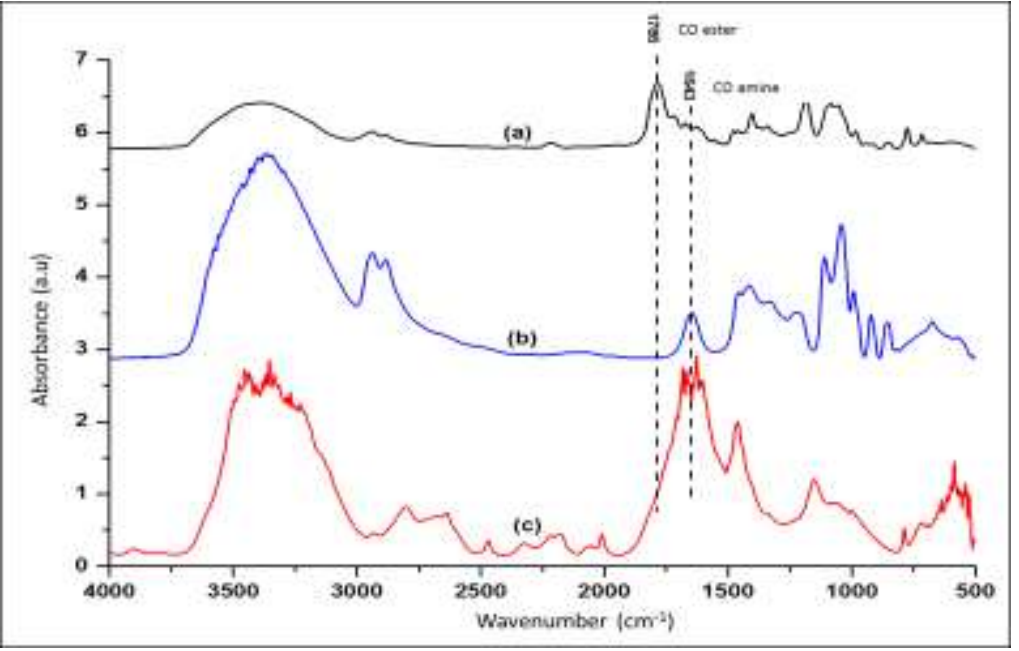

Figure 3. Glycerol Carbonate Spectra ; (a) calcined limestone catalyst at $\mathrm{T} 750^{\circ} \mathrm{C}$, (b) urea, and (c) glycerol

Identification using gas chromatography instruments (Gas Chromatography) was confirmed that the product (glycerol carbonate) have been formed and detected at a retention time of 17.5 minutes. This GC data reinforces FTIR data which shows that the synthesis of glycerol carbonate reaction 
from glycerol and urea using limestone was successfully carried out.

Based on the data from the research conducted starting from limestone preparation, catalytic reaction testing of glycerol and urea, and characterization of product, this has given us information that the local limestone of Kolaka has the potential to be further developed in the catalyst sector.

\section{Optimization of Catalytic Reaction}

Optimization of time is done at a time variation of $1 ; 2 ; 3 ; 4$ and 5 hours at the reaction time of 1 hour produced $35 \%$ of the product and increasingly stopped at the reaction time of 4 hours with a conversion amount of $71 \%$. the conversion decreased when the reaction exceeded 4 hours to 54\% (Table 2). FTIR analysis results show that there are other species formed besides glyserol carbonate, which are 5(hydroxymethyl) oxzolidin-2-on at 5 hours (Turney et al., 2013) which are characterized by the formation of $\mathrm{CO}$ carbamate vibrations at $1736 \mathrm{~cm}-1$.

Table 2. Effect of time on the conversion product

\begin{tabular}{ccc}
\hline Number & $\begin{array}{c}\text { Time } \\
\text { (hour) }\end{array}$ & $\begin{array}{c}\text { convertion } \\
(\boldsymbol{\%})\end{array}$ \\
\hline 1 & 1 & 35 \\
\hline 2 & 2 & 39 \\
\hline 3 & 3 & 46 \\
\hline 4 & 4 & 71 \\
\hline 5 & 5 & 54 \\
\hline
\end{tabular}

Temperature optimization of the glycerol carbonate formation reaction was carried out in the range of $120-160^{\circ} \mathrm{C}$ (table $3)$. The table shows that at a temperature of $140^{\circ} \mathrm{C}$ gives the best increase in conversion to $58 \%$, while at a temperature of $150-160^{\circ} \mathrm{C}$ the conversion decreases to $13 \%$. This decrease in conversion is caused by the formation of a side product species namely 5- (hydroxymethyl) oxozolidin-2one at wave number $1736 \mathrm{~cm}-1$ (Turney et al., 2013). This species is formed at temperatures above $150^{\circ} \mathrm{C}$.

Table 3 . Effect of temperature on the conversion of product

\begin{tabular}{ccc}
\hline Number & $\begin{array}{c}\text { Temperature } \\
\left({ }^{\mathbf{}} \mathbf{C}\right)\end{array}$ & $\begin{array}{c}\text { Convertio } \\
\mathbf{n}(\boldsymbol{\%})\end{array}$ \\
\hline 1 & 120 & 34 \\
\hline 2 & 130 & 46 \\
\hline 3 & 140 & 58 \\
\hline 4 & 150 & 21 \\
\hline 5 & 160 & 13 \\
\hline
\end{tabular}

Exp: reaction conditions: 5\% cao mass to glycerol, glycerol-urea mole ratio $=1: 1$, reaction temperature $140^{\circ} \mathrm{c}$, reaction time 4 hours. glycerol carbonate conversion is calculated based on the results of analyzes using gas chromatography.conclusion

Optimization of the amount of catalyst to the conversion is also done, the reaction is carried out by varying the catalyst concentration ie $0 \%, 1 \%, 2 \%, 2.5 \%$ and $5 \%$ mass of the substrate. Based on Table 4 the $\mathrm{CaO}$ catalyst has a good activity of a concentration of $1 \%$ to glycerol, whereas without the addition of the catalyst the reaction of glycerol with urea runs very slowly and results in very low conversion. The best conversion of the amount of catalyst is $2.5 \%$ and $5 \%$ with conversions reaching $51 \%$ and $71 \%$.

Tabel 4. Effect of catalyst concentration in conversion

\begin{tabular}{ccc}
\hline Number & $\begin{array}{c}\text { Catalyst } \\
\text { concentration } \\
(\boldsymbol{\%})\end{array}$ & $\begin{array}{c}\text { Convertion } \\
(\boldsymbol{\%})\end{array}$ \\
\hline 1 & 0 & 6 \\
\hline 2 & 1 & 9 \\
\hline 3 & 2 & 11 \\
\hline 4 & 2,5 & 51 \\
\hline 5 & 5 & 71 \\
\hline
\end{tabular}

Exp: Reaction conditions: 5\% cao mass to glycerol, glycerol-urea mole ratio $=1: 1$, reaction temperature $140^{\circ} \mathrm{c}$, reaction time 4 hours. Glycerol carbonate conversion is calculated based on the results of analyzes using gas chromatography.conclusion 


\section{CONCLUSION}

The test of catalytic activity of $\mathrm{CaCO} 3$ and $\mathrm{CaO}$ from limestone for the synthesis of glycerol carbonate was successfully carried out. synthesis of glycerol carbonate from technical glycerol and urea was carried out with optimum reaction conditions at a temperature of $140 \mathrm{oC}$ for 4 hours, using mole ratio of $5 \%$ catalyst to substrate

\section{ACKNOWLEDGEMENTS}

Thank you to the Directorate General of Strengthening Research and Development of the Ministry of Research, Technology and Higher Education as a provider of research funding and community service based on research contract decision letter Number 009 / SP2HL/LT/DRPHM / 2018, and the Research, Community Service and Quality Assurance Institute Education (LP2M-PMP) of Universitas Sembilanbelas November Kolaka for the help, guidance and information provided during the research.

\section{REFERENCES}

Adhitasari, A., Sulistyo, H., dan Prasetya, A., Synthesis of Glycerol Carbonate from Glycerol and Urea Using Indion Resin Catalysts $225 \mathrm{Na}$, Reaktor, 2017, 17(3) :139-143

Damayanti, O. Synthesis of Glycerol Carbonate From Glycerol With Nickel Based Catalysts. Institut Teknologi Sepuluh Nopember, Surabaya. Jurnal Teknik ITS, 2012, 1( 1): 2301-9271

Hammond,C., Lopez-Sanchez, J.A., Ab Rahim, M.H., Dimitratos, N., Jenkins, R.L., Carley, A.F., He, Q., Kiely, C.J., Knight, D.W., Hutchings, G.J. Synthesis of Glycerol Carbonate From Glycerol and Urea With Gold-Based Catalysts. Dalton Trans 2011,40 : 3927-37

Jimmy, Nilna, F., Huda, M.I., Jehadu, Y.M., Synthesis of Glycerol Carbonate from
Glycerol (Biodiesel Industrial Residue) with Variations Reactant Ratios and Reaction Times, National Seminar on Technology 2015, National Technology Institute of Malang

Lailiyah, Q., Baqiya, M., Darminto. Effect of Temperature and Flow Rate of $\mathrm{CO}_{2}$ Gas on Synthesis of Calcium Carbonate Precipitate by Bubbling Method. Jurnal Sains dan Seni ITS, 2012, Vol. 1(1)

Lukman, M., Yudyanto., Hartatiek. Synthesis of $\mathrm{CaO}-\mathrm{SiO}_{2}$ Composite Biomaterials Based on Natural Materials (Limestone and Quartz Sand) with Heating Temperature Variations and Their Effects on Porosity, Hardness and Microstructure. Journal Sains 2012, 2(1).

Ochoa-Gómez, J. R. Synthesis of glycerol carbonate from glycerol and dimethyl carbonate by transesterification: Catalyst screening and reaction optimization. Appl. Catal. A Gen, 2009 $.366: 315-324$

Rubio-Marcos, F., Calvino-Casilda, V., Bañares, M. a. \& Fernandez, J. F. Novel hierarchical $\quad \mathrm{Co}_{3} \mathrm{O}_{4} / \mathrm{ZnO}$ mixtures by dry nanodispersion and their catalytic application in the carbonylation of glycerol. J. Catal 2010 . $275: 288-293$.

Sucipto, E., (2007). The Relationship of Dust Particle Exposure to Limestone Processing to Lung Capacity Decrease. Semarang: Diponegoro University.

Turney, T. W., Patti, A., Gates, W., Shaheen, U. \& Kulasegaram, S. Formation of glycerol carbonate from glycerol and urea catalysed by metal monoglycerolates. Green Chem 2013.15 : 19-25

Wang, L., Ma, Y., Wang, Y., Liu, S. \& Deng, Y. Efficient Synthesis Of Glycerol Carbonate From Glycerol And Urea with Lanthanum Oxide As a Solid Base 
Catalyst. Catal. Commun 2011, 12 :1458-1462.

Zhang, Y., Dubé, M., McLean, D.\& Kates, M. Biodiesel Production From Waste Cooking oil: 2. Economic Assessment and Sensitivity Analysis. Bioresour. Technol. 2003, 90 : 229-240 